\title{
Prostacyclin Synthase
}

National Cancer Institute

\section{Source}

National Cancer Institute. Prostacyclin Synthase. NCI Thesaurus. Code C96440.

Prostacyclin synthase (500 aa, $\sim 57 \mathrm{kDa}$ ) is encoded by the human PTGIS gene. This protein plays a role in the mediation of prostaglandin biosynthesis. 